\title{
DESKRIPTIVNI PROFIL TJELESNE STRUKTURE VRHUNSKIH RVAČA GRČKO-RIMSKOG STILA DEFINISAN METODOM MULTIKANALNE BIOELEKTRIČNE IMPEDANCE
}

\author{
Goran Kasum $^{1}$ i Milivoj Dopsaj ${ }^{1}$
}

${ }^{1}$ Fakultet sporta i fizičkog vaspitanja, Univerzitet u Beogradu, Srbija

\section{SAŽETAK}

Zbog specifičnosti sporta i težinskih kategorija rvači se odlikuju i specifičnim morfološkim karakteristikama. Sa razvojem novih tehnologija mjerenja stvaraju se i nove mogućnosti za usavršavanje načina dobijanja novih informacija značajnih za sistem sporta. Jedna od novih tehnologija, koja se primenjuje u prostoru mjerenja strukture tjelesnog sastava je metod bioimpedance, a najnovije generacije koriste varijantu multikanalne bioelektrične bioimpedance. Cilj ovog rada je da definiše morfološki model vrhunskih rvača seniorskog uzrasta, primjenom tehnološki najnovije metode, čime će se izvršiti revalidacija postojećih saznanja o datom prostoru. Uzorak ispitanika je bio sastavljen od 22 ispitanika muškog pola, rvača iz discipline grčko-rimski, takmičara vrhunskog seniorskog nivoa iz četiri zemlje: Srbija $(n=10)$, Hrvatska $(n=9)$, Crna Gora $(n=2)$ i Grčka $(n=1)$. Mjerenje tjelesnog sastava je izvršeno metodom multikanalne bioelektrične impedance pomoću profesionalnog aparata najnovije generacije - InBody 720 Tetrapolar 8-Point Tactile Electrode System (Biospace, Co., Ltd). Najvažniji rezultat ovog istraživanja je definisanje generičkog (opšteg) četvorodimenzionalnog modela (4D model) sastava tijela u funkciji kvalitetnih rvača međunarodne klase koji ima sljedeće karakteristike (u odnosu na prosječnu tjelesnu masu rvača iz uzorka - 81,95 kg): sadržaj vode iznosi 55,08 Lili 67,24\%, količina proteina iznosi 15,00 kg ili 18,33 \%, masa minerala iznosi 4,98 kg ili 5,97\% i masa masti iznosi $6,99 \mathrm{~kg}$ ili 8,49\%.

Ključne riječi: rvači grčko-rimskog stila, bioimpedanca, tjelesni sastav, model.

\section{UVOD}

Većina stručnjaka i naučnika koji se bave morfologijom sportista, smatra da između sporta kojim se on bavi i njegovih morfoloških karakteristika, postoji dijalektička veza. Naime, u većini slučajeva, mladi sportista se oprjedeljuje baš za sport koji najviše odgovara njegovoj morfologiji, jer upravo morfologija i predstavlja u određenoj mjeri njegovu tjelesnu prednost. Sa druge strane, baveći se odabranim sportom, usljed fenomena adaptacije na sportske napore, sportista vremenom dobija sve izraženije karakteristike tipične za taj sport. Pokazalo se da, što su sportska dostignuća veća, to su ona u tjesnijoj vezi sa sastavom i građom tijela sportista (Bajić, Ponorac, Rašeta i Bajić, 2010; Obradović i saradnici, 2011; Yoon, 2002). Zato se u većini sportova značajna pažnja poklanja posmatranju i izučavanju antropološkog statusa aktivnih spotista, ali i onih koji tek namjeravaju da se bave nekim od sportova (Khani, Farokhi, Shalchi, Angoori i Ansari, 2011; Rupčić, Matković, Knjaz, Baščevan i Rodić, 2011; Schmidt, Piencikowski i Vandervest, 2005). Poznavanje individualnih osobenosti sportista koji se aktivno bave rvanjem, neophodan je preduslov za uspješnu izradu kvalitetnih programa po kojima će se raditi i upravljanje trenažnim procesom (Станков, КАимин і Письмеский, 1984). Među mnogim osobenostima koje svaki sportista posjeduje, morfološke karakteristike su, sasvim sigurno, jedna od onih koje veoma značajno utiču na ostvarivanje značajnih sportskih rezultata. Zato se one sa posebnom pažnjom prate i analiziraju, kao polazište, odnosno morfološki status na početku trenažnog procesa, ali i kao cilj, odnosno morfološki status kakvom treba težiti (Kasum i Obradović, 2008). 
Rvači se odlikuju specifičnim morfološkim karakteristikama, čija su osnovna obilježja: naglašene širine i obimi tijela, proporcionalno dugačke ruke i kraće noge, velik procenat aktivne mišićne tjelesne mase (Борисов і Туманян, 1973). Po klasifikaciji Bunaka (Станков i saradnici, 1984), postoje tri osnovna konstitucionalna tipa boraca (grudni, muskularni i trbušni), i četiri prelazna (grudno - muskularni, muskularno - grudni, muskularno - trbušni i trbušno - muskularni). Grudni tip boraca karakteriše dobro razvijen grudni koš i snažan rameni pojas. Muskularni tip karakterišu cilindrični oblik grudnog koša, jak i ravan stomak, dobro razvijeni mišići i umjerene naslage sala. Trbušni tip karakterišu konični oblik grudnog koša, ispupčen stomak, povijena leđa, značajne masne naslage i srednja muskulatura. Postoji čitav niz morfoloških pokazatelja koji se prate i analiziraju, a mogu značajno uticati na izbor tehika koje takmičar najčešće koristi u borbi (Kasum i Radović, 2009). Tu se prije svega misli na longitudinalne i transverzalne dimenzije skeleta i dijametre zglobova, koji su u značajnoj mjeri određeni nasljednim faktorima. Ipak, uočeno je da se pobjednici najvećih rvačkih takmičenja, u poređenju sa ostalim takmičarima iste težinske kategorije, često imaju izraženije longitudinalne dimenzije (Kasum, 2001).

Uticaj dugotrajnog treninga na neke morfološke pokazatelje može biti značajan, ali na njih nije moguće značajnije uticati planski. Ovo je slučaj sa koštanim sistemom, koji kod rvača, pod uticajem naprezanja, dobija veću specifičnu težinu, ali i zapreminu (Аныш, 1999). Uočeno je da se šampioni Evrope, svijeta i Olimpijskih igara razlikuju od ostalih rvača iz reprezentacije po tome, što imaju veće apsolutne i relativne veličine koštanog i mišićnog tkiva, i manje veličine potkožnog, unutrašnjeg i ukupnog masnog tkiva. Slične rezultate dobili su Туманян і Мартиросов (1974), a oni smatraju da takav odnos komponenata težine tijela predodređuje odgovarajuću specifičnu težinu tijela rvača, koja je najveća kod predstavnika najmanjih težinskih kategorija, a najmanja kod predstavnika teške kategorije.

Za izračunavanje sastava tijela postoji više različitih formula. Sve one koriste podatke koji su dobijeni antropometrijskim mjerenjima. Na taj način se dobijaju vrijednosti mišićnog, koštanog i masnog tkiva, u apsolutnim i relativnim vrijednostima. Tako su Моргунова, Патратия і Старков (1985), na osnovu uzorka od 138 rvača slobodnim stilom iz sastava reprezentacije SSSR, koristeći formulu I. Matiegka, napravili tablice osnovnih parametara sastava tijela rvača, u pripremnom i takmičarskom periodu. Oni su ustanovili da apsolutne vrijednosti mišićnog, koštanog i masnog tkiva rastu od najnižih ka najvišim težinskim kategorijama, dok se srednje relativne vrijednosti mišićnog tkiva kod rvača kreću od 48,37 do $52,50 \%$ (minimum 43,67, maksimum 56,46\%), srednje relativne vrijednosti koštanog tkiva od 14,20 do $16,92 \%$ (minimum 12,39, maksimum 23,88 \%), a srednje relativne vrijednosti masnog tkiva od 8,44 do 17,43\% (minimum 5,57, maksimum 27,44\%). Isti autori su ustanovili da procenat masnog tkiva raste od najnižih ka najvišim težinskim kategorijama, procenat koštanog tkiva opada sa težinom ispitivanih rvača, dok kod procenta mišićnog tkiva nije uočena neka jasna zakonitost. Poređenjem 12 parametara sastava tijela rvača, od čega su 7 pokazatelji apsolutnih, a 5 pokazatelji relativizovanih vrijednosti, konstatovno je da se kod svih 12 pokazatelja morfološkog statusa javljaju razlike između vrijednosti dobijenih tokom pripremnog i takmičarskog perioda. Ipak, statistički značajne razlike konstatovane su samo za vrijednosti apsolutne i relativne količine potkožnog masnog tkiva, za vrijednosti ukupne količine masti u telu, kao i za relativne vrijednosti mišićnog tkiva.

Sa razvojem novih tehnologija mjerenja, otvaraju se i nove mogućnosti za usavršavanje načina dobijanja novih informacija značajnih za sistem sporta. Jedna od novih tehnologija, koja se primjenjuje u prostoru mjerenja strukture tjelesnog sastava je metod bioimpedace, a najnovije generacije koriste varijantu multikanalne bioelektrične bioimpedance, koja kao metod postaje zlatni standard u istraživanjima morfologije ljudi (InBody 720 Biospace, 2008).

Cilj ovog rada je da definiše morfološki model vrhunskih rvača seniorskog uzrasta, primjenom tehnološki najnovije metode, čime će se izvršiti revalidacija postojećih saznanja o datom prostoru.

\section{METODE}

\section{Uzorak}

Uzorak ispitanika je bio sastavljen od 22 ispitanika muškog pola, koji su se takmičili u rvačkom sportu u disciplini grčko-rimski stil na vrhunskom seniorskom nivou. Ispitanici su pripadali reprezentacijama sljedećih zemalja: Srbija $(n=10)$, Hrvatska $(n=9)$, Crna Gora $(n=2)$ i Grčka $(n=1)$. Svi su bili upoznati sa uslovima testiranja i dobrovoljno su učestvovali u istraživanju. Osnovni deskriptivni karakteristike uzorka su bili: uzrast $=23,1 \pm 2,4$ god., $\mathrm{BH}=175,7 \pm 8,96 \mathrm{~cm}, \mathrm{BM}$ $=81,95 \pm 14,75 \mathrm{~kg}, \mathrm{BMI}=26,33 \pm 2,43 \mathrm{~kg} / \mathrm{m}^{2}$, bavljenje rvanjem $=12,5 \pm 2,7$ god., nedjeljna učestalost treninga $=9,5 \pm 0,9$ treninga/sedmično, sumarni obim nedjeljnog trenažnog rada $=842,4 \pm 139,2 \mathrm{~min}$ treninga/sedmično. Istraživanje je realizovano u skladu 
sa uslovima "Deklaracija iz Helsinkija sa prijedlozima smjernica ljekarima u biomedicinskim istraživanjima koji uključuju čovjeka" - (http://www.cirp.org/library/ ethics/helsinki/), a uz odobrenje i saglasnost Etičke komisije Fakulteta sporta i fizičkog vaspitanja Univerziteta u Beogradu.

\section{Procedure testiranja}

Mjerenje tjelesnog sastava je izvršeno metodom bioelektrične impedance (Bioelectrical Impedance Analysis - BIA), pomoću profesionalnog aparata najnovije generacije - InBody 720 Tetrapolar 8-Point Tactile Electrode System (Biospace, Co., Ltd). Aparat InBody 720 koristi najnoviju tehnologiju mjerenja tjelesnog sastava primjenom DSM-BIA metode (Direct Segmental Multi-frequency Bioelectrical Impedance Analysis), gde se upotrebom različitog raspona frekvencije od $1 \mathrm{KHZ}$ do $1 \mathrm{MHz}$ pomoću metode reaktivnosti mjeri količina/masa sve četiri glavne tjelesne komponente - voda, proteini, minerali i masti i to tačnošću od: $92,2 \%$ za područje viscelarne masti (VFA) do 98,0\% za slobodne masne mase (FFM) (InBody 720 Biospace, 2008).

Sva mjerenja su izvršena u periodu Mart - April 2010, tokom finalnih faza priprema za EP u rvanju, a ispitanici su bili upoznati sa svim preduslovima mjerne procedure (Ibid):

- mjerenja su realizovana u jutarnjim časovima (između 9:00 i 10:00 časova); veče prije mjerenja ispitanici nisu uzimali hranu poslije 21:00 časova, a na dan mjerenja nisu doručkovali niti pili tečnost prije završetka mjernog postupka;

- 12 sati prije mjerenja ispitanici nisu imali velika fizička tj. trenažna naprezanja; ispitanici su prije mjerenja obavili sve osnovne fiziološke potrebe;

- 48 sati prije mjerenja ispitanici nisu konzumirali alkohol; prije samog mjerenje ispitanici su stajali najmanje 5 minuta, radi preraspodjele tjelesnih tečnosti u tkivima;

- mjerenje je izvršeno u stojećoj poziciji po proceduri koju je preporučio proizvođač (ruke odmaknute 150 od tela).

\section{Varijable}

Ovim istraživanjem je obuhvaćeno ukupno 23 varijabli, i to 13 osnovnih i 10 izvedenih (indeksnih) varijabli kojima je definisana morfološka struktura i sastav tijela.

Osnovne varijable za definisanje morfološke strukture i sastava tijela bile su:
- TM - tjelesna masa, izražena u kg;

- BMI - indeks tjelesne mase, izražen u $\mathrm{kg} / \mathrm{m}^{2}$;

- ICW - unutarćelijska tečnost, izražena u L;

- ECW - vanćelijska tečnost, izražena u L;

- TBW - ukupna tjelesna tečnost, izražena u L;

- Protein, izraženi u kg;

- Minerali, izraženi u kg;

- BMC - mineralni sadržaj kostiju, izražen u kg;

- BFM - masna masa tijela, izražena u kg;

- SMM - masa skeletnih mišića, izražena u kg;

- BCM - ćelijska masa tijel, izražen u kg;

- VFA - područje viscelarne masti, izražen u cm²;

- Fitness_SCORE, skor tjelesnog sastava - izražen kao numerički ekvivalent;

Izvedene (indeksne) varijable za definisanje morfološke strukture i sastava tijela bile su:

- TBW\% - procenat ukupne tjelesne tečnosti, izračunata kao: TBW / BM - izražen u \%;

- Proteini $\%$, procenat proteina, izračunato kao: Proteini / BM, izraženo u \%;

- $\mathrm{BMC} \%$ - procenta BMC, izračunat kao: BMC / BM, izražen u \%;

- PBF, procenat tjelesne masti, izračunat kao: BFM / BM - izražen u \%;

- $\mathrm{SMM} \%$ - procenat od indeksa glatke mišićne mase, izračunat kao: SMM / BM, izražen u \%;

- $\mathrm{BCM} \%$ - procenat od ćelijske mase tijela, izračunat kao: BCM / BM, izražen u \%;

- PFI - indeks proteina i masti, izračunat kao odnos između proteina i masne mase tijela, izražen u kg;

- BSI - indeks čvrstoće kostiju, izračunat kao odnos između BMC i BM, izražen u g/kg;

- $\mathrm{BMI} / \mathrm{PBF}$ index - izračunat kao odnos između BMI i PBF, izražen u $\mathrm{kg} / \mathrm{m}^{2}$ po $1 \%$ masti;

- Indeks raspodjele masti (VFA/BF), kao relacija između VFA i BF, izražen u $\mathrm{cm}^{2}$ visceralne masti po $1 \mathrm{~kg}$ masne mase tijela.

\section{Statistička obrada podataka}

Svi rezultati su prvo podvrgnuti deskriptivnoj statističkoj analizi radi definisanja osnovnih mjera centralne tendencije i disperzije podataka $(\mathrm{M}, \mathrm{SD}$, $\mathrm{cV} \%$, SE, 95\% intervala pouzdanosti - donja i gornja granica). Za oblik distribucije su korišćene mjere spljoštenosti i zakrivljenosti (skjunis i kurtosis), dok je izračunavanje pravilnosti distribucije korišćenih varijabli upotrebljen neparametrijski test KolmogorovSmirnov. Sve statističke analize su realizovane primjenom softvera SPSS Statistics 17.0. (SPSS Statistics, Inc.). 


\section{REZULTATI}

\section{Rezultati osnovnih morfoloških varijabli}

Rezultati osnovne deskriptivne statistike, kao i parcijalne komparativne analize osnovnih morfoloških varijabli mjerenog uzoraka ispitanika (Wrestlers $/ n=$ 22), prikazani su u Tabeli 1.

\section{Rezultati izvedenih [indeksnih) morfoloških varijabli}

Rezultati osnovne deskriptivne statistike izvedenih (indeksnih) morfoloških varijabli mjerenih uzoraka ispitanika $(\mathrm{W} / n=22)$ prikazani su u Tabeli 2.

\section{DISKUSIJA}

$\mathrm{Na}$ generalnom nivou, adekvatan tjelesni sastav jedan je od faktora koji u značajnoj mjeri ima uticaja u smislu izbora preferentnih tehnika i formiranja specifičnog stila rvanja (Kasum i Radović, 2009), kao i postizanja takmičarske uspješnosti na najvećim takmičenjima (Jagiełło i Kruszewski, 2005; Jagiełło, Tkaczuk i Kruszewski, 2004). Dati uticaj je u određenim sportovima još značajniji, a naročito je to slučaj u sportivima gdje postoje težinske kategorije, odnosno u borilačkim sportovima i sportovima snage kao što je npr. dizanje tegova (Jagiełło i Kruszewski, 2009).

Usavršavanjem tehnologije samo po sebi, usavršava se i izrada novih mjernih instrumenata, što kao

TABELA 1

Pokazatelji deskriptivne statistike osnovnih morfoloških varijabli mjerenog uzoraka ispitanika.

\begin{tabular}{|c|c|c|c|c|c|c|c|c|c|c|c|}
\hline \multirow{2}{*}{ Varijable } & \multirow{2}{*}{ M } & \multirow{2}{*}{$S D$} & \multirow{2}{*}{$c V \%$} & \multirow{2}{*}{ Min } & \multirow{2}{*}{ Max } & \multirow{2}{*}{ Skew } & \multirow{2}{*}{ Kurt } & \multirow{2}{*}{ SE } & \multicolumn{2}{|c|}{$\begin{array}{l}95 \% \text { intervala } \\
\text { pouzdanosti }\end{array}$} & \multirow{2}{*}{$\mathrm{K}-\mathrm{S} p$} \\
\hline & & & & & & & & & $\begin{array}{c}\text { Donja } \\
\text { granica }\end{array}$ & $\begin{array}{l}\text { Gornja } \\
\text { granica }\end{array}$ & \\
\hline TM (kg) & 81,95 & 14,39 & 17,56 & 61,50 & 118,20 & 0,66 & 0,42 & 3,07 & 76,60 & 87,30 & 0,852 \\
\hline BMI $\left(\mathrm{kg} / \mathrm{m}^{2}\right)$ & 26,33 & 2,37 & 9,00 & 21,78 & 31,25 & 0,33 & 0,34 & 0,51 & 25,34 & 27,33 & 0,850 \\
\hline ICW (L) & 34,71 & 6,10 & 17,57 & 26,10 & 52,80 & 1,12 & 2,46 & 1,30 & 32,58 & 36,84 & 0,728 \\
\hline ECW (L) & 20,37 & 3,83 & 18,80 & 15,50 & 31,20 & 0,99 & 1,68 & 0,82 & 19,04 & 21,70 & 0,552 \\
\hline TBW (L) & 55,08 & 9,91 & 17,99 & 41,80 & 84,00 & 1,08 & 2,17 & 2,11 & 51,63 & 58,53 & 0,816 \\
\hline Proteini (kg) & 15,00 & 2,62 & 17,47 & 11,30 & 22,80 & 1,13 & 2,52 & 0,56 & 14,06 & 15,91 & 0,731 \\
\hline Minerali (kg) & 4,89 & 0,99 & 20,25 & 3,60 & 7,77 & 0,99 & 2,03 & 0,21 & 4,55 & 5,24 & 0,927 \\
\hline BMC (kg) & 4,00 & 0,83 & 20,75 & 2,87 & 6,39 & 0,98 & 1,87 & 0,18 & 3,71 & 4,29 & 0,986 \\
\hline BFM (kg) & 6,99 & 3,28 & 46,92 & 2,30 & 17,00 & 1,18 & 2,89 & 0,70 & 4,74 & 9,23 & 0,942 \\
\hline SMM (kg) & 43,26 & 7,96 & 18,40 & 32,00 & 66,90 & 1,12 & 2,48 & 1,70 & 40,50 & 46,02 & 0,722 \\
\hline BCM (kg) & 49,71 & 8,73 & 17,56 & 37,40 & 75,60 & 1,11 & 2,44 & 1,86 & 46,67 & 52,76 & 0,723 \\
\hline VFA $\left(\mathrm{cm}^{2}\right)$ & 46,60 & 20,11 & 43,15 & 20,20 & 95,40 & 0,76 & 0,12 & 4,29 & 36,57 & 56,64 & 0,935 \\
\hline Fitness_SCORE & 96,90 & 8,11 & 8,37 & 85,00 & 120,00 & 1,06 & 2,06 & 1,73 & 93,05 & 100,00 & 0,545 \\
\hline
\end{tabular}

Legenda: M - Aritmetička sredina; SD - Standardna devijacija; cV\% - Koeficijent varijacije u procentima; Min - Minimum; Max - Maksimum; Skew - Skjunis; Kurt - Kurtozis; SE - Standardna greška; K-S p - Kolmogorov-Smirnov vjerovatnoća; TM - Tjelesna težina; BMI - Indeks tjelesne mase; ICW - Unutarćelijska tečnost; ECW - Vanćelijska tečnost; TBW - Ukupna tjelesna tečnost; BMC - Mineralni sadržaj kostiju;

BFM - Masna masa tijela; SMM - Masa skeletnih mišića; BCM - Ćelijska masa tijela; VFA - Područje vicelarne masti.

posledicu ima uspostavljanje novih instrumenata i procedura mjerenja, što sve zajedno obezbjeđuje uslove za novi saznajni potencijal kojim se postojeći nivo znanja poboljšava. Cilj ovog rada je bio da primjenom nove tehnologije - multikanalne električne bioimpedance definiše generički / opšti/ deskriptivni profil tjelesnog sastava vrhunskih rvača grčko-rimskog stila, kao i da etablira nove indikatore definisane kao indeksne vrijednosti za procjenu istog.

Rezultati su pokazali da distribucija svih analiziranih varijabli nije različita od hipotetski pravilne, ta se može tvrditi da se rezultati mogu interpretirati kao validni 
TABELA 2

Osnovna deskriptivna statistika izvedenih (indeksnib) morfoloških varijabli mjerenih uzoraka ispitanika.

\begin{tabular}{|c|c|c|c|c|c|c|c|c|c|c|c|}
\hline \multirow{2}{*}{ Varijable } & \multirow{2}{*}{ M } & \multirow{2}{*}{$S D$} & \multirow{2}{*}{$c V \%$} & \multirow{2}{*}{ Min } & \multirow{2}{*}{ Max } & \multirow{2}{*}{ Skew } & \multirow{2}{*}{ Kurt } & \multirow{2}{*}{ SE } & \multicolumn{2}{|c|}{$\begin{array}{c}95 \% \text { intervala po- } \\
\text { uzdanosti }\end{array}$} & \multirow{2}{*}{$\mathrm{K}-\mathrm{S} p$} \\
\hline & & & & & & & & & $\begin{array}{l}\text { Donja } \\
\text { granica }\end{array}$ & $\begin{array}{l}\text { Gornja } \\
\text { granica }\end{array}$ & \\
\hline TBW\% (\%) & 67,24 & 2,51 & 3,73 & 60,91 & 71,41 & $-0,42$ & 0,76 & 0,54 & 65,61 & 68,88 & 0,658 \\
\hline Proteins $\%(\%)$ & 18,33 & 0,70 & 3,84 & 16,46 & 19,62 & $-0,46$ & 1,25 & 0,15 & 17,86 & 18,79 & 0,779 \\
\hline BMC \% (\%) & 4,86 & 0,24 & 4,96 & 4,45 & 5,41 & 0,41 & 0,10 & 0,51 & 4,73 & 4,98 & 0,965 \\
\hline PBF\% $\%(\%)$ & 8,49 & 3,36 & 39,58 & 2,95 & 17,17 & 0,42 & 1,03 & 0,72 & 6,28 & 10,70 & 0,579 \\
\hline SMM\% $\%(\%)$ & 52,79 & 2,06 & 3,90 & 47,78 & 56,79 & 0,44 & $-0,03$ & 0,96 & 51,45 & 54,13 & 0,658 \\
\hline BCM $\%(\%)$ & 60,74 & 2,32 & 3,82 & 54,75 & 65,13 & $-0,34$ & 1,02 & 0,50 & 59,19 & 62,30 & 0,884 \\
\hline PFI $(\%)$ & 2,69 & 1,54 & 57,30 & 0,96 & 6,65 & 1,60 & 1,82 & 0,33 & 2,18 & 3,21 & 0,051 \\
\hline BSI $(\%)$ & 0,0486 & 0,0024 & 4,94 & 0,0445 & 0,0541 & 0,41 & 0,10 & 0,0005 & 0,047 & 0,05 & 0,965 \\
\hline $\mathrm{BMI} / \mathrm{PBF}$ index $(\%)$ & 3,79 & 2,11 & 55,68 & 1,82 & 9,70 & 1,89 & 2,90 & 0,45 & 3,11 & 4,47 & 0,056 \\
\hline $\mathrm{VFA} / \mathrm{BF}(\%)$ & 7,267 & 2,959 & 40,73 & 2,802 & 17,00 & 2,02 & 5,44 & 0,631 & 6,30 & 8,23 & 0,174 \\
\hline
\end{tabular}

Legenda: M - Aritmetička sredina; SD - Standardna devijacija; cV\% - Koeficijent varijacije u procentima; Min - Minimum; Max - Maksimum; Skew - Skjunis; Kurt - Kurtozis; SE - Standardna greška; K-S p - Kolmogorov-Smirnov vjerovatnoća; TBW\% - Procenat ukupne tjelesne vode; Proteins \% - Procenat proteina; BMC\% - Procenat mineralnog koštanog sadržaja; PBF\% - Procenat tjelesne masti; SMM\% - Procenat od indeksa glatke mišićne mase; BCM\% - Procenat od ćelijske mase tijela; PFI - Indeks proteina i masti; BSI - Indeks čvrstoće kostiju; VFA/BF - Indeks raspodjele masti.

i pouzdani, bez obzira da li se radi o originalnim ili izvedenim (indeksinim) varijablama (Tabela 1 i 2 , od $\mathrm{K}-\mathrm{S} p=0,986$ za BMC do $p=0,051$ za PFI).

U odnosu na tjelesnu masu (TM) izmjerena prosječna vrijednost testiranog uzorka je bila $81,95 \pm 14,39 \mathrm{~kg}$ sa rasponom rezultata od 61,5 do 118,2 kg. Kako je testirani uzorak rvača bio sastavljen od svih težinskih kategorija, podatak o prosječnoj masi ima informativni karakter.

U odnosu na indeks tjelesne mase (BMI) izmjerena prosječna vrijednost testiranog uzorka je bila $26,33 \pm$ $2,37 \mathrm{~kg} / \mathrm{m}^{2}$ sa graničnim vrijednostima od 21,78 do $31,25 \mathrm{~kg} / \mathrm{m}^{2}$. Na osnovu intervala pouzdanosti (95\% vjerovatnoće) može se tvrditi da se kod vrhunskih rvača optimalne vrijednosti BMI nalaze u rasponu od 25,34 do $27,33 \mathrm{~kg} / \mathrm{m}^{2}$. Imajući u vidu činjenicu da su testirani uzorak činili vrhunski rvači uz čak 4 zemlje regiona (Srbija, Hrvatska, Crna Gora i Grčka) može se prihvatiti kao činjenica da je dati raspon BMI takmičarski optimalan u odnosu na kvantitativno obilježje indeksa mase tijela populacije rvača balkanskog regiona.

Podaci o količini tečnosti u organizmu (Tabele 1 i 2) su pokazali da je prosječna mjera hidriranosti testiranih rvača bila na nivou od 34,71 \pm 6,10 litara sadržaja tečnosti u ćelijama (ICW), 20,37 \pm 3,83 litara sadržaja tečnosti u vanćelijskom prostoru (ECW), da je ukupna količina vode u tijelu bila na nivou od 55,08 \pm 9,91 litara ukupne tečnosti u organizmu (TBW). Izmjerena količina TBW je predstavljala 67,24 \pm 2,51\% ukupne mase tijela (TBW\%). Data varijabla je imala karakteristike veoma homogene veličine sa minimalnom varijacijom od samo $3,73 \%$, veoma malom greškom mjerenja metode od samo $0,54 \%$, i intervalom pouzdanosti od 65,61 do 68,88\%.

U svakom slučaju i količina vode je podatak koji ima veliki značaj za rvače. Prekomjerno gubljenje tečnosti dovodi do dehidracije organizma, a svaka dehidracija dovodi i do gubljenja elektrolita. Elektroliti koji su ustvari joni rastvoreni u tečnosti, imaju funkciju kod predaje nervnih inpulsa i skraćivanja mišića, odnosno svih fizioloških funkcija. Pošto se tečnost $u$ organizam unosi preko želudačno crijevnog trakta, a eliminiše preko znojnih žlijezda i bubrega, organizam (posebno bubrezi) čini napor da sačuva odgovarajuću koncentraciju elektrolita. Međutim, ako je proces dehidracije suviše brz, nasilan ili suviše dugotrajan, koncentracija elektrolita se sve više narušava. Čak i malo narušavanje elektrolitnog balansa, manifestuje se opštom slabošću, slabljenjem umnih funkcija i gubljenjem mišićne koordinacije. Pri pretjeranoj dehidraciji organizma, narušava se funkcija bubrega, 
dolazi do smanjenja obima krvi i do gubljenja unutarćelijske tečnosti.

U odnosu na varijable statusa kontraktilnog tkiva (proteini i skeletni mišići) rezultati su pokazali da je izmjerena prosječna vrijednost proteina od 15,00 \pm $2,62 \mathrm{~kg}$, sa rasponom od minimalnih 11,30 do maksimalnih $22,80 \mathrm{~kg}$, i intervalom pouzdanosti od 14,06 do 15,9 kg mase proteina. U odnosu na utvrđenu masu skeletnih mišića (SMM) prosječna vrijednost kod uzorka je bila 43,26 \pm 7,96 kg sa rasponom od minimalnih 32,00 do maksimalnih $66,90 \mathrm{~kg}$, i intervalom pouzdanosti od 40,50 do 46,02 $\mathrm{kg}$ mase skeletnih mišića. Vrijednost procenta proteina u tijelu (Proteins\%) je bila na nivou od $18,33 \pm 0,70 \%$ proteina $/ \mathrm{kg}$ TM (interval pouzdanosti $=17,86-18,79 \%$ ), dok je u odnosu na testirani uzorak vrhunskih rvača procenat skeletnih mišić bio 52,79 $\pm 2,06 \% \mathrm{SMM} / \mathrm{kg}$ TM (interval pouzdanosti $=51,45-54,13 \%$ ). Kao mjera odnosa proteinske i masne komponente, u ovom radu je korišćen inovativni index (PFI) i utvrđeno je da kod vrhunskih rvača na $1 \mathrm{~kg}$ masnog tkiva ima $2,69 \mathrm{~kg}$ proteinske mase, odnosno vrijednost datog indeksa je bila na nivou od 2,69 $\pm 0,70 \%$ proteina/BFM uz interval pouzdanosti od 2,18 do $3,21 \%$.

Imajući u vidu činjenicu da u rvanju postoje težinske kategorije, težnju svih rvača da imaju što veći procenat mišićnog tkiva nije moguće realizovati forsiranom hipertrofijom mišića. Naime, čak i dobitak čiste mišićne mase može predstavljati problem ako rvača dovodi u situaciju da prinudno mijenja takmičarsku kategoriju. Zato u treningu rvača mora da dominira trening snage zasnovan na unapređenju neurogenih faktora, čiji je cilj aktiviranje najvećeg broja motornih jedinica sa najboljom frekvencijom pražnjenja, što se postiže visokim intenzitetom i nešto manjim obimom treninga. Pri tome, potrebno je na istom treningu koristiti vježbe za različite grupe mišića, ali i koristiti različte vježbe za iste grupe mišića. Na taj način se dobija muskulatura koja je tipična za rvače, koju karakterišu snažne tetive i ne previše hipertofirani mišići. Veliki problem predstavlja i gubitak mišićne mase prilikom redukovanja tjelesne težine. Poznato je da mišići imaju čak tri puta veću specifičnu težinu nego masno tkivo, tako da gubitak težine vrlo često nije pravi pokazatelj efikasnosti redukovanja tjelesne težine. Nije rijetkost da rvači izgube i više od 8 kilograma a da im se procenat masnog tkiva poveća, što najbolje ilustruje činjenicu da je regulisanje težine rađeno stihijski i bez uvažavanja neki osnovnih principa. I ovo istraživanje registrovalo je slučaj rvača koji je izgubio čak 9,6 kg tjelesne težine, a pri tome "uspjeo" da poveća apsolutnu vrijednost masti za 0,1 kg, odnosno da procenatualno poveća količinu masti za $0,7 \%$. Ovako naglašen gubitak mase bio je posljedica gubitka 7,1 litra vode, odnosno čak $5,4 \mathrm{~kg}$ čiste mišićne mase. Naravno, rezultat ovakvog regulisanja težine je nastup na takmičenju koji nije ni vrijedan spomena.

Već je ranije utvrđeno da rvači kao sportisti, gde dominiraju visoko razvijene kontraktilne karakteristike (različiti aspekti ispoljavanja karakteristika mišićne sile i mišićne snage) kao posljedica adaptacije na trening i takmičenje imaju i naglašenu mezomorfnu konstituciju, odnosno imaju naglašenu muskulaturu - mišićnu komponentu. Posljedično, pomenuta adaptacija se pored mišićne komponente reflektuje i na masnu komponentu, gdje je utvrđeno da se u toku takmičarskog dijela sezone vrijednost procenta masnog tkiva (PBF) kod vrhunskih rvača nalazi u rasponu od 4 do $10 \%$, sa izuzetkom superteške kategorije kod koje postoji veliki stepen različitosti kod date varijable (Yoon, 2002). Skoro istovijetni rezultati o PBF su utvrđeni i u ovom istraživanju jer je prosječna vrijednost date varijable bila $8,49 \pm 3,36 \% \mathrm{BF} / \mathrm{BM}$ uz interval pouzdanosti od 6,28 do $10,70 \%$. U odnosu na ukupnu vrijednost masti u organizmu prosjek testiranih rvača je bio na nivou od samo $6,99 \pm 3,28 \mathrm{~kg}$ uz interval pouzdanosti od 4,74 do 9,23 kg. Prosječna vrijednost visceralne masti je bila $49,71 \pm 8,72 \mathrm{~cm}^{2}$ (interval pouzdanosti $=36,57$ do $\left.56,64 \mathrm{~cm}^{2}\right)$, dok su prosječne vrijednosti dvije indeksne varijable (BMI/PBF index i VFA/BF), kao indikatori distribucije masnog tkiva u telu (Deurenberg-Yap, Schmidt, vanStaveren, Hautvast i Deurenberg, 2001) bile na nivou od 3,79 $\pm 2,11 \mathrm{~kg} /$ $\mathrm{m}^{2}$ po $1 \%$ masti i $7,267 \pm 2,959 \mathrm{~cm}^{2}$ visceralne masti po $1 \mathrm{~kg}$ masne mase tijela (Tabela 2).

Poznato je da se pri opterećenjima produženog trajanja (duže od 30 minuta), kao i umjerenog intenziteta, pri pulsu $60-70 \%$ od maksimalnog, čak $85 \%$ energije dobija iz masti (Đorđević, 2005). Ova činjenica je razlog što u takmičarskom mezociklusu trening rvača često uključuje i opterećenja umerjenog intenziteta, koja inače nisu karakteristična za rvačku borbu, već je uobičajeno da rvači, koji ozbiljnije redukuju svoju težinu, pri kraju treninga trče u krug oko sale u kojoj su prethodno rješavali tehničko-taktičke zadatke. Naravno, opterećenja nešto većeg intenziteta takođe uključuju masti kao izvor energije, ali je manji procenat energije dobijen iz masti, a već pri pulsu $80 \%$ od maksimalnog svega $50 \%$ energije dobija se iz masti. U svakom slučaju, procenat masnog tkiva se mora minimizirati, a pokazatelji dobijeni na uzorku vrlo kvalitetnih rvača mogu predstavljati referentne vrijednosti i neku vrstu preporučenih vrijednosti. Ovi pokazatelji mogu varirati u toku godine i nešto su niži u takmičarskom nego u predtakmičarskom mezociklusu, ali te razlike obično nisu statistički značajne (Schmidt 
i saradnici, 2005).

Međutim, kada su tjelesne težine iz takmičarskog mezociklusa upoređene sa težinama u prelaznom perodu, konstatovne su i statistički značajne razlike (Buford, Rossi, Smith, O’Brien i Pickering, 2006). U prelaznom periodu su moguća određena opuštanja po pitanju kontrole tjelesne težine, ali ta odstupanja od standardne težine ne bi smjela da budu suviše velika, zato što i proces sagorjevanja masti u organizmu zahtijeva postupnost i vrijeme. Preporučuje se da nedeljno skidanje masti bude između 1,2 i 2 kilograma, a u ovom periodu treba uzimati hranu bez masti, koja sadrži minerale i vitamine, naročito B kompleks, kao i smanjenu količinu ugljenih hidrata i bjelančevina (Kasum, Jovanović i Ćirković, 2002). Ukoliko je težina tijela znatno veća od uobičajene, ulazi se u problem regulisanja težine i njenog redukovanja do propisane granične vrijednosti.

U odnosu na mineralnu komponentu utvrđeno je da je ukupna masa minerala u tijelu 4,89 $\pm 0,99 \mathrm{~kg}$ uz interval pouzdanosti od 4,55 do 5,24 kg, da mineralna masa koštanog dijela (Osseous) iznosi 4,00 \pm 0,83 kg uz interval pouzdanosti od 3,71 do 4,29 kg. Procentualna zastupljenost mineralnog dijela koštane mase u odnosu na masu tijela nalazi se na nivou od 4,86 $\pm 0,24 \%$ (od 4,73 do $4,98 \%$ ), odnosno posmatrano preko BSI indeksa, čija je prosječna vrijednost $0,0486 \pm 0,0024$, na 1 kilogram tjelesne mase proporcijalno postoji 48,6 grama minerala koštanog tkiva (Tabela 2).

Testirani rvači iz uzorka su imali 49,71 $\pm 8,73 \mathrm{~kg}$ mase živih ćelija u organizmu (BMC - Body Cell Mass) što predstavlja $60,74 \pm 2,32 \%$ zastupljenosti u organizmu (Tabele 1 i 2).

$\mathrm{Na}$ kraju, prosječna ocjena sastava tijela (Fitness SCORE) je bila 96,90 $\pm 8,11$ bodova, sa rasponom intervala povjerenja od 93,05 do 100,00 bodova.

$\mathrm{Na}$ Slici 1 je prikazan 4D model sastava tijela kod testiranih rvača sa sljedećim modelnim karakteristikama: u odnosu na prosječnu tjelesnu masu rvača iz uzorka - 81,95 kg, sadržaj vode iznosi 55,08 L ili 67,24 \%, količina proteina iznosi 15,00 kg ili 18,33 \%, masa minerala iznosi 4,98 kg ili 5,97\% i masa masti iznosi 6,99 kg ili 8,49\%.

\section{SLIKA 1}

4D model sastava tijela testiranih rvača.

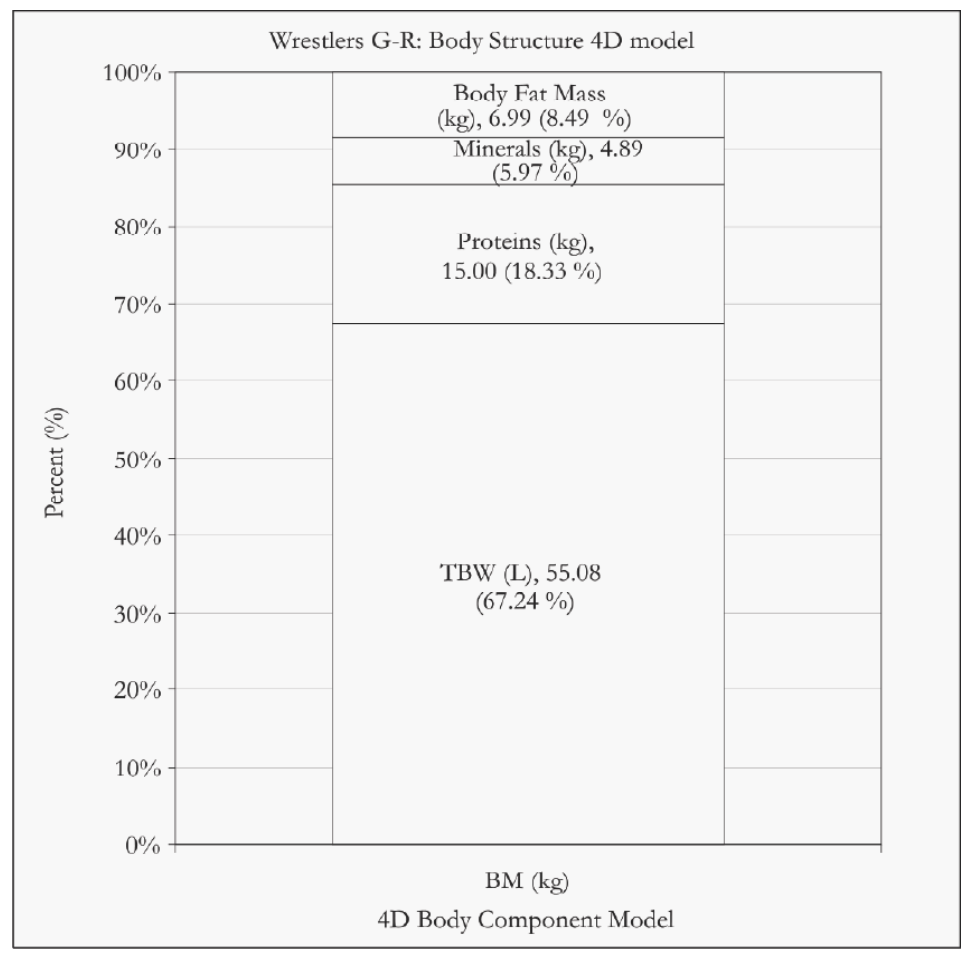

Legenda: Wrestlers G-R (Greco-Roman): Body structure 4D model - Rvači G-R (grčko-rimski): 4D model strukture tijela; Body Fat Mass - Masa masti u tjelu; Minerals - Minerali; Proteins - Proteini; TBW - Total body water (Ukupna voda u tijelu); BM - Body mass (Tjelesna masa); 4D Body Component Model - 4D model komponenti tijela; Percent - Procenat. 


\section{ZAKLJUČAK}

Rezultati ovog istraživanja su pokazali da kod kvalitetnih rvača, procenat masnog tkiva u prosjeku iznosi $8,49 \%$ ukupne mase tijela, uz minimalnu i maksimalnu vrijednost ukupne mase tijela na nivou od 2,95\% i 17,17\%, odnosno uz interval pouzdanosti od 6,28 do 10,70\%. Imajući u vidu činjenicu da u rvanju postoje težinske kategorije, veće količine masnog tkiva predstavljaju nepotreban balast, koji se mora maksimalno redukovati.

Nasuprot masnom tkivu, kod rvača je veoma poželjan visok procenat mišićnog tkiva. Rezultati ovog istraživanja su pokazali da kod kvalitetnih rvača, procenat čiste mišićne mase u prosjeku iznosi 52,79\% ukupne mase tela, uz minimalnu zabelježenu vrijednost $47,78 \%$ i maksimalnu vrijednost od čak $56,79 \%$ ukupne mase tijela, odnosno uz interval pouzdanosti od 51,45 do 54,13\%. Imajući u vidu činjenicu da u rvanju postoje težinske kategorije, težnju svih rvača da imaju što veći procenat mišićnog tkiva nije moguće realizovati forsiranom hipertrofijom mišića. Naime, čak i dobitak čiste mišićne mase može predstavljati problem ako rvača dovodi u situaciju da prinudno mijenja takmičarsku kategoriju.

U svakom slučaju i količina vode je podatak koji ima veliki značaj za rvače. Prekomjerno gubljenje tečnosti dovodi do dehidracije organizma, a svaka dehidracija dovodi i do gubljenja elektrolita. Rezultati ovog istraživanja su pokazali da je kod kvalitetnih rvača prosječna mjera hidriranosti bila na nivou od 34,71 \pm 6,10 litara sadržaja tečnosti u ćelijama (ICW), $20,37 \pm 3,83$ litara sadržaja tečnosti u vanćelijskom prostoru (ECW), odnosno da je ukupna količina vode u tijelu bila na nivou od 55,08 \pm 9,91 litara (TBW). Izmjerena količina TBW je predstavljala 67,24 $\pm 2,51 \%$ ukupne mase tijela (TBW\%). Data varijabla je imala karakteristike veoma homogene veličine sa intervalom pouzdanosti od 65,61 do $68,88 \%$.

Međutim, najvažniji rezultat ovog istraživanja je definisanje generičkog (opšteg) četvorodimenzionalnog modela (4D model) sastava tijela u funkciji kvalitetnih rvača međunarodne klase, koji ima sljedeće karakteristike: u odnosu na prosječnu tjelesnu masu rvača iz uzorka - 81,95kg, sadržaj vode iznosi 55,08 1 ili 67,24\%, količina proteina iznosi 15,00 kg ili 18,33\%, masa minerala iznosi 4,98 kg ili 5,97\% i masa masti iznosi $6,99 \mathrm{~kg}$ ili 8,49\%.

\section{ZAHVALNOST}

Ovaj rad je dio programskog projekta finansiranog od strane Ministarstva nauke i tehnološkog razvoja Republike Srbije (no. III47015, 2011-2014).

\section{LITERATURA}

Аныш, А. С. (1999). ВАияние физических упражнений на мышцы [Influence of physical exercise on muscles]. Неопубликованный реферат. БАаговещенск: Амурский государственный университет.

Bajić, Z., Ponorac, N., Rašeta, N., \& Bajić, Đ. (2010). Uticaj fizičke aktivnosti na kvalitet kosti [Influence of physical activity on bone quality]. SportLogia, 6(1), 7-13. doi: 10.5550/sgia.1001007

Борисов, J. А., \& Туманян, Г. С. (1973). Обьем сердца и его зависимость от размеров тела у борцов [Volume of the heart and its dependence on body size in wrestlers]. ТПФК, 11, 37-40.

Buford, T. W., Rossi, S. J., Smith, D. B., O'Brien, M. S., \& Pickering, C. (2006). The effect of a competitive wrestling season on body weight, hydration, and muscular performance in collegiate wrestlers. The Journal of Strength \& Conditioning Research, 20(3), 689-692. doi: 10.1519/R-19955.1; doi: 10.1519/00124278200608000-00034

Deurenberg-Yap, M., Schmidt, G., van Staveren, W. A., Hautvast, J. G. A. J., \& Deurenberg, P. (2001). Body fat measurement among Singaporean Chinese, Malaysand Indians: acomparative study using a four-compartment model and different two-compartment models. British Journal of Nutrition, 85, 491-498. doi: 10.1079/BJN2000276; PMid: 11348564

Đorđević, A. (2005). Skidanje masnih naslaga kod rekreativaca [Fat loss for recreationists]. Sportska medicina, 5(3), 150-179.

InBody 720, The Precision Body Composition Analyzer, Manuel for Use, 1996-2008 Biospace Co., Ltd, Seoul, Korea. (2008).

Jagiełło, W., \& Kruszewski, A. (2005). Profil strojenia tela sbornoj komandy Polszi po klasiczeskoj borbe [Profile body build Poland's national team in a classic wrestling]. In S. S. Jermakowi (Ed.), Fiziczeskoje wospitanije studentów tworczeskich specjalnostej (pp. 88-95). Charków, PL: HGADI (HHPI).

Jagiełło, W., \& Kruszewski, A. (2009). Morphological diversification of competitors training Greko-Roman style of wrestling. Archives of Budo, 5, 147-153.

Jagiełło, W., Tkaczuk, W., \& Kruszewski, A. (2004). Morfofunkcjonalne aspekty efektiwnosti sorewnowatelnoj dejatelnosti sportsmenok, specjalizirujuszczichsja w wolnoj borbe [Morfofunctional aspects of efficacy of activity sportswomans in freestyle wrestling]. In S. S. 
Jermakowa (Ed.), Pedagogika, psychologia ta medikobiologiczny problemy fizicznogo wichowanija $i$ sportu (pp. 93-104). Charków, PL: HDADM (HHPI).

Kasum, G. (2001). Kritički osvrt na 48. Evropsko prvenstvo u rvanju grčko-rimskim stilom. [Critical review on the 48th European Championships in Greco-Roman wrestling] Fizickea kultura, 55(1-4), 127-129.

Kasum, G., Jovanović, S., \& Ćirković, Z. (2002). Problem regulisanja telesne težine kod mladih rvača [Problem of regulating body weight in young wrestlers]. Godisnjak, 11, 168-171.

Kasum, G., \& Obradović, Z. (2008). Efekti i uticaji trenažnog procesa na antropometrijski status u rvanju [Effects and impacts of the training process on the anthropometric status in wrestling]. In J. Babiak (Ed.), Prvi naučno - strućni medunarodni simpozijum "Efekti i uticaji razlicitith modela trenažnog procesa na antropološki status sportista u borilačkim sportovima" (pp. 23-27). Pančevo, RS: Pokrainski zavod za sport Novi Sad i SO Pančevo.

Kasum, G., \& Radović, M. (2009). Connection of some morphological characteristics of best wrestlers and their main scoring techniques. In S. Wlodzimierz and B. Jevtić (Eds.), 10th Sport Kinetics Conference Belgrade 2007 "New ideas in fundamentals of Human Movement: current issues and perspective" (pp. 287-295). Belgrade, RS: IASK.

Khani, M., Farokhi, A., Shalchi, B., Angoori, P., \& Ansari, A. (2011). The relationship of personality dimensions and self-regulation components to the success of Iranian boxers. Serbian Journal of Sports Sciences, 5(1-4), 21-28.

Мартиросов, Э. Г., \& Туманян, Г. С. (1974). Морфологические и функчиональные особенности боруов в связи со спортивныли достижениями [Morphological and functional features of the fighters in connection with sports achievements]. Вопросы антропологии. Москва, RU: МГУ.

Моргунов, Ю. А., Потратий, Р. С., \& Старкова, Е. С. (1985). Состав тела атлетов, занимающихся вольной борьбой [Body composition of athletes engaged in freestyle wrestling]. ТПФК, 4, 19-22.

Obradović, B., Jakšić, D., Matić, R., Milošević, Z., Bubanj, S., \& Bubanj, R. (2011). The correlation between anthropometric, motor and the variables for the evaluation of bone density. Facta universitatis - series: Physical Education and Sport, 9(3), 265-274.

Rupčić, T., Matković, B., Knjaz, D., Baščevan, S., \& Rodić, S. (2011). Differences in physiological load of the referees with concideration to the period of the basketball game. SportLogia, 7(1), 84-94. doi: 10.5550/sgia.120081.en.051R; doi: 10.5550/sgia.120081.se.047R

Schmidt, W. D., Piencikowski, C. L., \& Vandervest, R. E. (2005). Effects of A Competitive Wrestling Season on Body Composition, Strength, and Power in National Collegiate Athletic Association Division III College Wrestlers. The Journal of Strength \& Conditioning Research, 19(3), 505-508. doi: 10.1519/R-15014.1; doi: 10.1519/00124278200508000-00004

Станков, А. Г., КАимин, Б. П., \& Письмеский, И. А. (1984). Индивидуализачия подготовки боруов [Individualization of fighters practice]. Москва, RU: Физкультура и спорт.

Yoon, J. (2002). Physiological profiles of elite senior wrestlers. Sports Medicine, 32(4), 225-233. doi: 10.2165/00007256-200232040-00002; PMid: 11929352

Primljeno: 1. novembar 2012 Izmjene primljene: 1. decembar 2012

Odobreno: 23. decembar 2012

Korespondencija: Dr Goran Kasum

Fakultet sporta i fizičkog vaspitanja Blagoja Parovića 156 11000 Beograd Srbija

Telefon: 00381642710252

E-mail: goran.kasum@fsfv.bg.ac.rs 